\title{
Development of a Model to Predict the Extraction of Juice from Date Palm Fruit
}

\author{
Sunday Reagan Ogblechi ${ }^{1}$, Moses Toye Ige $^{2}$ \\ ${ }^{1}$ Nigerian Institute for Oil Palm Research (NIFOR), Agricultural Engineering Research Division, Benin City, Nigeria \\ ${ }^{2}$ Department of Agricultural \& Environmental Engineering, Faculty of Technology, Obafemi Awolowo University, Ile-Ife, Nigeria
}

Email address:

reaganogblechi@gmail.com (S. R. Ogblechi), mosesige63@yahoo.com (M. T. Ige)

\section{To cite this article:}

Sunday Reagan Ogblechi, Moses Toye Ige. Development of a Model to Predict the Extraction of Juice from Date Palm Fruit. Bioprocess Engineering. Vol. 2, No. 3, 2018, pp. 24-32. doi: 10.11648/j.be.20180203.11

Received: January 2, 2019; Accepted: February 7, 2019; Published: February 26, 2019

\begin{abstract}
A model for predicting juice extraction from date palm fruit using an existing mechanical extractor was developed in the study. Model development was based on principle of continuity and momentum transport. Optimum values of factors such as steaming time, diffusion coefficient, digestion time and quantity of water required for optimum juice yield were determined. Effect of steaming time, diffusion coefficient and pressure on experimental and predicted yield were also determined. Results obtained gave optimum values for steaming time, diffusion coefficient, digestion time and quantity of water as 90 minutes, $4.38 \times 10^{-9} \mathrm{~m}^{2} / \mathrm{s}, 15$ minutes and 8 litres, respectively. Statistical analysis showed that the effects of factors on yield were significant $(\mathrm{P}<0.01)$. The overall deviation of experimental yield from theoretical prediction was $2.56 \%$. The results obtained showed that the mechanical extractor been optimized in the study is appropriate to be applied for economic purposes.
\end{abstract}

Keywords: Model, Predicting, Juice, Extraction, Mechanical Extractor, Developed, Factors, Optimum, Economic

\section{Introduction}

Modelling juice extraction from fruit is possible when the extraction and operation parameters are known. The modelling process involves the development of mathematical equations using available facts or results obtained from experimentation. It is a step by step process which is based on scientific principles and logics. Models are simulated in order to predict outcomes that have addressed all defects or most of the inadequacies that accompany a particular problem or design. Models are useful in process control and optimization since they are used to predict process efficiencies for a wide range of process conditions. They serve as veritable tools in improving operational performance of process equipment through design. Models facilitate design changes for varying input materials without opting for expensive experimentations.

It was learnt from literature that extraction of juice from fruit is based on three phenomena which are juice flow through cell wall, flow through inter-mesocarp voids and flow through compressed biomass (mash). Hagen poiseuille equation for flow of fluids in pipes is used to describe the flow of substrate through pores in cell wall [1]. Darcy's law of fluid flow through porous media is used to describe flow of fluid through inter-mesocarp voids and a modified form of Terzaghi's equation for consolidation of saturated juice to describe the flow behaviour of compressed biomass [1].

Table 1. Symbols used and definition.

\begin{tabular}{llll}
\hline Symbol & Definition & Symbol & Definition \\
\hline $\mathrm{t}$ & time (seconds) & $S_{e}^{2}$ & error associated with experimental yield \\
$\mathrm{t}_{\mathrm{s}}$ & steaming time (seconds) & $S_{p}^{2}$ & error associated with predicted yield \\
$\partial$ & partial derivative & $\ddot{\mathrm{X}}_{\mathrm{p}}$ & mean of predicted yield \\
$\rho$ & density & $\ddot{\mathrm{X}}_{\mathrm{e}}$ & mean of experimental yield \\
$\partial_{t} \rho$ & change in density with respect to time & $\mathrm{n}_{\mathrm{e}}$ & frequency of experimental yield \\
$\mathrm{V}$ & Velocity vector & $\mathrm{n}_{\mathrm{p}}$ & frequency of predicted yield \\
\hline
\end{tabular}




\begin{tabular}{llll}
\hline Symbol & Definition & Symbol & Definition \\
\hline$\sigma$ & standard deviation & $\mathrm{S}_{\mathrm{d}}$ & standard error of difference \\
$\mathrm{M}$ & mass $(\mathrm{kg})$ & $\mathrm{C}_{\mathrm{f}}$ & diffusion coefficient of date palm fruit $\left(\mathrm{m}^{2} / \mathrm{s}\right)$ \\
$\mathrm{A}$ & area $\left(\mathrm{m}^{2}\right)$ & $\mathrm{k}$ & \\
$\Delta \mathrm{P}=\mathrm{P}_{2}-\mathrm{P}_{1}$ & change in pressure $(\mathrm{MPa})$ & & \\
$\mathrm{L}$ & length of extractor $(\mathrm{m})$ & & \\
$l$ & length of macerator $(\mathrm{m})$ & & \\
\hline
\end{tabular}

The distribution of extractable materials within a solid structure is a factor of the model to be developed. Some extraction models used for the removal of fluid from plants may be classified into two main groups as follow:

i. Empirical models.

ii. Differential mass balance models.

\subsection{Empirical Models}

These are based on results obtained from experimentation. Extraction factors such as speed of flow, pressure, temperature, particle size, solubility, time of activity, etc were used in the development of extraction models [2].

\subsection{Differential Mass Balance Model}

Differential mass balance model was based on conservation of mass, energy and momentum. This has three basic classifications: (i) mass transfer, (ii) heat transfer and (iii) shrinking core.

(i) Model based on mass transfer [3-6]

The model predicted the extraction of material when there was a difference in the concentration of the material to be extracted and the bulk phase that contained solid and solvent [7].

(ii) Model based on heat transfer [8-10]

The model for the separation process was based on heat transfer phenomenon. Each plant cell was assumed to be spherical in shape and the equation for a cooling hot sphere in a cold medium was used to express the concentration profile inside a particle as a function of time [7].

(iii) Shrinking core model

Plant cell was assumed to be spherical in shape. The extraction process described an irreversible desorption or removal of materials by diffusion through pores in porous media.

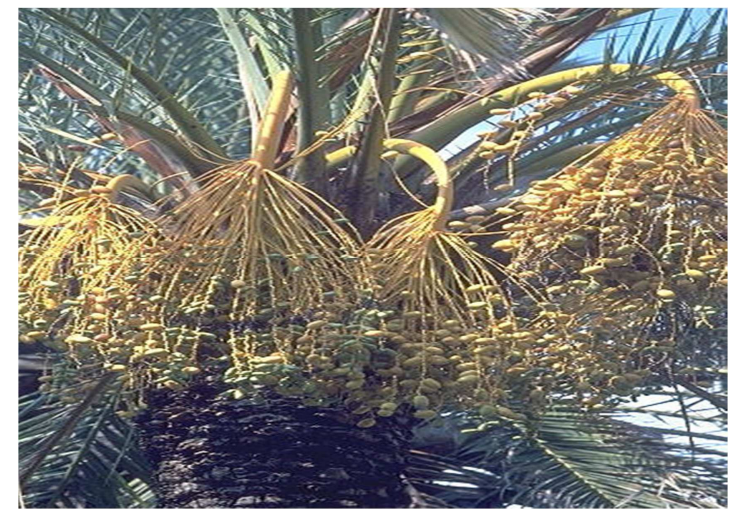

Figure 1. Date palm with fruits.
In the current study, the major focus was to develop a model to predict the extraction of juice from date palm fruit. The fruit has nutritional and medicinal values [11-13], hence the interest on the crop. Table 1 shows symbols and their definitions as used in the study while Table 2 shows the composition of date palm fruit juice among other constituents [14]. Figure 1 shows some date palm fruits on a date palm.

Table 2. Composition of date palm fruit juice.

\begin{tabular}{ll}
\hline Substance & Quantity \\
\hline Vitamin C & $0.13 \mathrm{mg} / \mathrm{ml}$ \\
Proteins & $1.78 \%$ \\
Iron & $94.33 \mathrm{ppm}$ \\
Magnesium & $578.43 \mathrm{ppm}$ \\
Calcium & $127.93 \mathrm{ppm}$ \\
Phosphorus & $342.70 \mathrm{ppm}$ \\
Manganese & $31.00 \mathrm{ppm}$ \\
Copper & $16.60 \mathrm{ppm}$ \\
Potassium & $117.43 \mathrm{ppm}$ \\
Sodium & $0.10 \mathrm{ppm}$ \\
Total Sugars & $8.94 \%$ \\
Reducing Sugars & $7.13 \%$ \\
Total Solid & $8.99 \%$ \\
Titratable acidity & $0.48 \mathrm{~g} / 1$ \\
Ph & 5.07 \\
\hline
\end{tabular}

\section{Materials and Methods}

An existing mechanical extractor was used to develop a mathematical model to predict the extraction of juice from date palm fruit by applying some factors of extraction with water as solvent.

Optimum values of factors which were steaming time, diffusion coefficient, digestion time and quantity of water employed in the extraction process were determined. A $2^{4}$ factorial experimental design was employed to determine the effect of factors on yield with the determination of analysis of variance (anova) using System Analysis System [15]. Predicted and experimental yield were compared with each other.

\subsection{Materials}

The materials used in the research included the followings.

\subsubsection{Raw Materials}

Dry date palm fruits were obtained from Nigerian Institute for Oil Palm Research (NIFOR), Date Palm Substation, Dogon-Dutse, Jigawa State, Nigeria.

\subsubsection{Equipment}

(i) Date palm fruit juice extraction machine: This was the extractor used to extract juice from date palm fruit after appropriate fruit treatments with steaming, 
digestion/maceration and pressing.

(ii) Steaming vessel: It was used to hydrate dry date palm fruit using steam at atmospheric pressure in order to facilitate the digestion or maceration of the fruit. The maceration process of the fruit promoted solubilization of nutritive constituents of the fruit.

(iii) Prime mover: This was an 8 horse power diesel engine used as a prime mover to drive the mechanical extractor.

\subsubsection{Instrumentation}

(i) Digital weighing balance: A weighing balance of a maximum mass of $15 \mathrm{~kg}$ with a precision of $0.001 \mathrm{~g}$ was used for the determination of mass.

(ii) Thermometer: A digital temperature probe with a range of $-50{ }^{\circ} \mathrm{C}$ to $750{ }^{\circ} \mathrm{C}$ was used for temperature measurement.

(iii) Tachometer: This was a digital microprocessor which was used to measure the speed of machine shaft and prime mover in revolution per minute (rpm).

(iv) Rotary evaporator: This was used to separate the extracted juice into solvent (water) and solute (soluble solid).

(vi) Stopwatch: This was used for measuring time of experimental runs.

\subsection{Methods}

Model development was based on the principle of continuity which is the law of conservation of mass. The law stated that "materials and momentum lost are equal to materials and momentum gained in a transformation process" [16-18]. The vector form of equation of continuity was given by Eq. (1). The principle of continuity was used earlier by other researchers [19-22] for the development of models to predict extraction of substances from agricultural produce. It was on this basis that some factors involved in the extraction of date juice from date palm fruit using a mechanical extractor that the present model was developed. The extractor is a two-in-one-machine comprising a horizontal mechanical digester and a horizontal mechanical press. The digester was used to macerate steam-treated date palm fruits and subsequently transferred to the mechanical press where date kernel and other solid particles were removed to give date palm fruit juice (date juice).

$$
\partial_{t} \rho+\operatorname{div}(\rho v)=0 .
$$

\subsubsection{Model Development}

Figure 2 is the physical model of the extractor. The following assumptions were made for model development.

Assumptions:

- Material moved as a bulk.

- No radial movement between particles.

- Axial pressure considered.

- Radial pressure neglected.

- Force was applied to overcome friction at the walls.

- Net change in mass was zero.

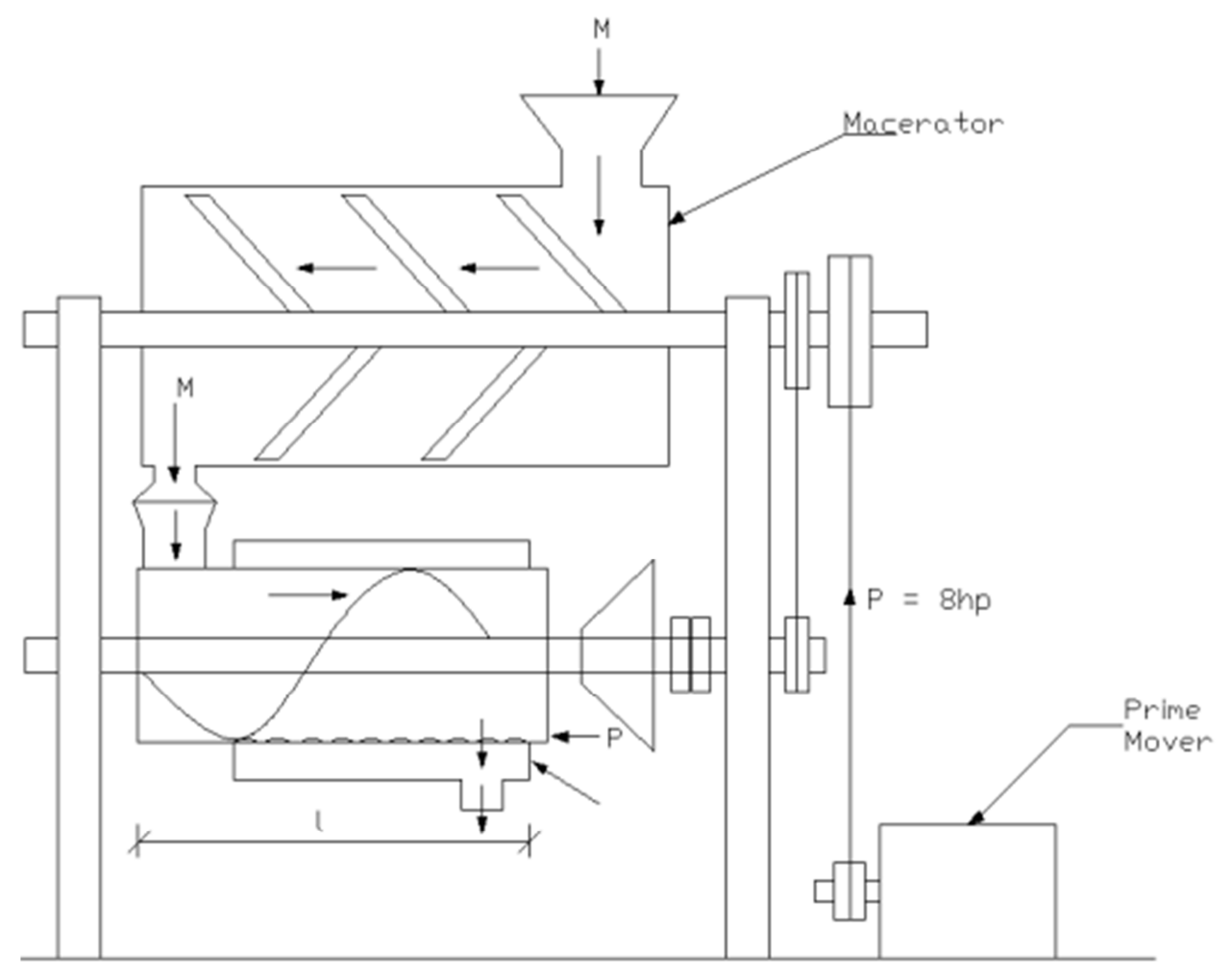

Figure 2. Physical model of the mechanical extractor.

(i) Fruit maceration

Maceration or digestion of date palm fruit of mass, $\mathrm{M}$ (kilogramme) at time, $\mathrm{t}$ (second) with bulk mass remaining constant was based on the principle of conservation of mass given by Eq. (2). Changed in mass with respect to time, t, was given as:

$$
\frac{d M}{d t}=0
$$


Assuming that during digestion the change in mass of date palm fruit with mass, $\mathrm{M}$ in $\mathrm{kg}$ at time, $\mathrm{t}$ (seconds) in an area given by $A$ in $\mathrm{m}^{2}$ with initial and final pressures as $\mathrm{P}_{1}$ and $\mathrm{P}_{2}$, respectively. The change in momentum of the digested mass over area, A with respect to pressure at the digester outlet was given as Eq. (3) which is based on the principle of momentum transport [16-18].

Rate of change of momentum at digester outlet $=\frac{d M}{d t} \mathrm{~A} \mathrm{p}_{2}$

(ii) Mash compression

The press chamber consists of an outer cylindrical pipe with radius, $r$ and length, $L$ housing a worm-shaft with an externally positioned choke mechanism. Pressure was developed in the cylindrical pipe during juice extraction. Extraction pressure considered was the axial pressure since radial movement of individual particles was ignored. The analysis of the press chamber was carried out as follows.

Surface area (A) of the cylinder $=2 \pi r l$,
Surface area of cylinder $=$ A.

Driving force $(\mathrm{F})$ in the cylinder when date palm fruits were in motion was given as:

Driving force $=$ Pressure $(\mathrm{P}) \times$ Area (A), that is

$$
\mathrm{F}=2 \pi r l \times P .
$$

The force responsible for motion and extraction of juice was influenced by pressure, machine/shaft speed, area of cylinder, diffusion coefficient of biomaterial, mass of biomaterial and volume of solvent (water) in the cylindrical element. These factors are defined as follow.

Area of cylindrical element $\left(\mathrm{m}^{2}\right)=\mathrm{A}$,

Diffusion coefficient of biomaterial $\left(\mathrm{m}^{2} / \mathrm{s}\right)=\mathrm{C}_{\mathrm{f}}$,

Volume of water/solvent (litres) $=\mathrm{Q}$,

Pressure $(\mathrm{MPa})=\mathrm{P}$.

Applying the principle of continuity being the law of conservation of mass which stated that materials and momentum lost are equal to materials and momentum gained in a process:

Output material $=$ Input material - Accumulation of material within the system.

Driving force (momentum flux) generated by the press $=A \Delta P$,

Force (momentum flux) generated by bulk material $=A M C_{f} t_{s} L$,

The net change in momentum flux within the press chamber was given as:

$$
A \Delta P-A M C_{f} t_{s} L=0 .
$$

The law of conservation of mass stated that a material undergoing some processes in a system could neither be destroyed nor created since change in mass is constant. There may be some transformations but summation of all masses after the process is equal to initial mass. That is material input is same as material output [16-18]. Applying the principle of continuity, Eq. (3) was equated to Eq. (8) to give Eq. (9).

$$
\frac{\mathrm{dM}}{\mathrm{dt}} \mathrm{AP}_{2}=A \Delta P-A M C_{f} t_{s} L=0,
$$

Substituting Eq. (4) in Eq. (9) gives Eq. (10).

$$
2 \pi r l \frac{d M}{d t} \mathrm{P}_{2}=2 \pi r l\left(P_{2}-P_{1}\right)-M 2 \pi r l \mathrm{C}_{\mathrm{f}} t_{s} L .
$$

Eq. (10) was the mathematical expression for the extraction of juice from date palm fruit. The equation was not suitable to predict juice yield and therefore, needed to be solved by separation of variables and substitutions coupled with differentiation and application of boundary conditions [23-25] to get the desired model.

Taken judgment from experimental observations and systematic combination of the continuity and momentum equations as stated above, Eq. (10) reduced to:

$$
\frac{d M}{d t}=\frac{M_{o}}{t_{o}} \frac{P_{2}-P_{1}}{P_{2}}-\frac{M_{o} C_{f} t_{S} L}{C_{f o}^{2} t_{o} P_{2}} M
$$

where $t_{0}, M_{o}$ and $C_{f o}$ were the time, mass and diffusion coefficient. Assuming that $\mathrm{t}_{\mathrm{o}}=\mathrm{M}_{\mathrm{o}}=\mathrm{C}_{\mathrm{fo}}=1$ (dimensionless quantities), then the above linear first order differential equation was written as:

$$
\frac{d M}{d t}+\frac{C_{f} t_{s} L}{P_{2}} M=\frac{P_{2}-P_{1}}{P_{2}} .
$$

By the integrating factor procedure,

$$
\frac{d}{d t}\left[M \exp ^{\left(\frac{C_{f} t_{S} L}{P_{2}} t\right)}\right]=\frac{P_{2}-P_{1}}{P_{2}} \exp ^{\left(\frac{C_{f} t_{s} L}{P_{2}} t\right)},
$$

which on integration became:

$$
\mathrm{M}=\frac{P_{2}-P_{1}}{C_{f} t_{s} L}+A \exp { }^{\left(-\frac{C_{f} t_{s} L}{P_{2}} t\right)},
$$

where A was a constant of integration. The value of A was determined using the initial conditions given as: $\mathrm{M}=0$ at $\mathrm{t}=$ 0 ,

$$
\begin{aligned}
& \mathrm{A}=-\frac{P_{2}-P_{1}}{C_{f} t_{s} L} \text {, then } \\
& \qquad \mathrm{M}=\frac{P_{2}-P_{1}}{C_{f} t_{S} L}\left[1-\exp ^{\left(-\frac{C_{\mathrm{f}} t_{s} L}{P_{2}} t\right)}\right] .
\end{aligned}
$$

The model for the extraction of juice from date palm fruit was therefore, given as:

$$
\mathrm{M}=\mathrm{K} \frac{P_{2}-P_{1}}{C_{f} t_{s} L}\left[1-\exp \left(-\frac{C_{f} t_{s} L}{P_{2}} t\right)\right] .
$$

Note that the presence of the constant $\mathrm{k}$ in the model, was to tune the model in order to adjust predicted yield to experimental yield. 
A programme for simulation of model to generate yield was developed using Matlab 7.9 (R2009b).

\subsection{Validation of the Model}

The model was validated by applying the method [26] which was based on determination of standard error of difference $\left(\mathrm{S}_{\mathrm{d}}\right)$ between predicted and experimental yield. The expression for the standard error of difference was given as:

$$
\mathrm{S}_{\mathrm{d}}=\left(\frac{\sum\left(\ddot{\mathrm{X}}_{p}-\ddot{\mathrm{X}}_{e}\right)^{2}}{\left(n_{p}+n_{e}\right)}\right)^{0.5}=\sqrt{\left(\frac{S_{p}^{2}}{n_{p}}+\frac{S_{e}^{2}}{n_{e}}\right)} .
$$

\section{Results and Discussion}

\subsection{Evaluation of Factors Involved in Extraction of Date Palm Fruit Juice}

Tables 3 and 4 show the yield obtained from a $2^{4}$ factorial experiment and the analysis of variance (anova), respectively. The effect of all the factors on yield were significant $(\mathrm{P}<0.01)$.

\subsubsection{Optimum Quantity of Water for Date Juice \\ Extraction}

The optimum quantity of water needed for extraction of juice from $1 \mathrm{~kg}$ date palm fruit was found to be 8 litres at $8.7^{\circ}$ Brix. When the quantity of water fell below the required water to fruit ratio, the extraction process became ineffective since bulk of the water-soluble-nutrients were not be released. On the other hand, if the water to fruit ratio $(8: 1)$ was exceeded, most of the water-soluble-nutrients were released but the concentration of the yield in terms of nutrients were low. Figure 3 shows the increase in yield (soluble-nutrient) with the corresponding increase in water. From Figure 3 it could be seen that maximum yield of soluble-nutrient was achieved at optimum quantity of water which was 8 litres. There was a steady decrease in solublenutrient beyond the optimum quantity of water. The graph also shows that the concentration of the juice in terms of sugar in Brix was maximum at quantity of water at 2 litres and decreased gradually with increased in water.

Table 3. Yield obtained using a $2^{4}$ factorial experiment.

\begin{tabular}{llllllll}
\hline $\mathbf{S} / \mathbf{N}$ & $\mathbf{Q}_{\mathbf{w}}$ & $\mathbf{S}_{\mathbf{t}}$ & $\mathbf{D}_{\mathbf{c}}$ & $\mathbf{M}_{\mathbf{t}}$ & $\mathbf{Y}$ ield & & \\
\hline & & & & & $\mathbf{Y}_{\mathbf{1}}$ & $\mathbf{Y}_{\mathbf{2}}$ & $\mathbf{Y}_{\mathbf{3}}$ \\
\hline 1 & 5 & 60 & 3.36578 & 10 & 0.12319 & 0.11931 & 0.12853 \\
2 & 8 & 60 & 3.36578 & 10 & 0.15582 & 0.15877 & 0.15472 \\
3 & 5 & 90 & 3.36578 & 10 & 0.16854 & 0.16972 & 0.16192 \\
4 & 8 & 90 & 3.36578 & 10 & 0.17954 & 0.17549 & 0.17752 \\
5 & 5 & 60 & 4.37552 & 10 & 0.16576 & 0.16084 & 0.16491 \\
6 & 8 & 60 & 4.37552 & 10 & 0.20157 & 0.20967 & 0.20755 \\
7 & 5 & 90 & 4.37552 & 10 & 0.22485 & 0.21415 & 0.23195 \\
8 & 8 & 90 & 4.37552 & 10 & 0.25881 & 0.24650 & 0.24756 \\
9 & 5 & 60 & 3.36578 & 15 & 0.14569 & 0.14951 & 0.14209 \\
10 & 8 & 60 & 3.36578 & 15 & 0.17455 & 0.17884 & 0.17195 \\
11 & 5 & 90 & 3.36578 & 15 & 0.19139 & 0.19834 & 0.19614 \\
12 & 8 & 90 & 3.36578 & 15 & 0.22756 & 0.23179 & 0.22692 \\
13 & 5 & 60 & 4.37552 & 15 & 0.25886 & 0.24709 & 0.25049 \\
14 & 8 & 60 & 4.37552 & 15 & 0.29119 & 0.28569 & 0.24682 \\
15 & 5 & 90 & 4.37552 & 15 & 0.35257 & 0.34719 & 0.33519 \\
16 & 8 & 90 & 4.37552 & 15 & 0.42964 & 0.40538 & 0.41853 \\
\hline
\end{tabular}

Note: $\mathrm{Q}_{\mathrm{w}}$ - Quantity of water; $\mathrm{S}_{\mathrm{t}}$ - Steaming time; $\mathrm{D}_{\mathrm{c}}$ - Diffusion coefficient; $\mathrm{M}_{\mathrm{t}}$ - Maceration time; $\mathrm{Y}$ - Yield;

Table 4. Analysis of variance showing effect of factors on yield.

\begin{tabular}{|c|c|c|c|c|c|c|}
\hline Source & DF & Type III SS & Mean square & F Value & $\operatorname{Pr}>\mathbf{F}$ & Effect \\
\hline $\mathrm{Q}_{\mathrm{w}}$ & 1 & 0.01381007 & 0.01381007 & 212.67 & $<.0001$ & ++ \\
\hline $\mathrm{S}_{\mathrm{t}}$ & 1 & 0.04837447 & 0.04837447 & 744.94 & $<.0001$ & ++ \\
\hline $\mathrm{D}_{\mathrm{c}}$ & 1 & 0.10972275 & 0.10972275 & 1689.7 & $<.0001$ & ++ \\
\hline $\mathrm{M}_{\mathrm{t}}$ & 1 & 0.05994154 & 0.05994154 & 923.07 & $<.0001$ & ++ \\
\hline Replicate & 2 & 0.00023808 & 0.00011904 & 1.83 & 0.1774 & NS \\
\hline $\mathrm{Q}_{\mathrm{w}} * \mathrm{~S}_{\mathrm{t}}$ & 1 & 0.00005716 & 0.00005716 & 0.88 & 0.3556 & NS \\
\hline $\mathrm{Q}_{\mathrm{w}} * \mathrm{D}_{\mathrm{c}}$ & 1 & 0.00064511 & 0.00064511 & 9.93 & 0.0037 & ++ \\
\hline $\mathrm{S}_{\mathrm{t}} * \mathrm{D}_{\mathrm{c}}$ & 1 & 0.00563316 & 0.00563316 & 86.75 & $<.0001$ & ++ \\
\hline $\mathrm{S}_{\mathrm{t}} * \mathrm{M}_{\mathrm{t}}$ & 1 & 0.00546045 & 0.00546045 & 84.09 & $<.0001$ & ++ \\
\hline$D_{c} * M_{t}$ & 1 & 0.01971576 & 0.01971576 & 303.61 & $<.0001$ & ++ \\
\hline $\mathrm{Q}_{\mathrm{w}} * \mathrm{~S}_{\mathrm{t}} * \mathrm{D}_{\mathrm{c}}$ & 1 & 0.00053007 & 0.00053007 & 8.16 & 0.0077 & ++ \\
\hline $\mathrm{Q}_{\mathrm{w}} * \mathrm{~S}_{\mathrm{t}} * \mathrm{M}_{\mathrm{t}}$ & 1 & 0.00157542 & 0.00157542 & 24.26 & $<.0001$ & ++ \\
\hline $\mathrm{S}_{\mathrm{t}} * \mathrm{D}_{\mathrm{c}} * \mathrm{M}_{\mathrm{t}}$ & 1 & 0.00160725 & 0.00160725 & 24.75 & $<.0001$ & ++ \\
\hline $\mathrm{Q}_{\mathrm{w}} * \mathrm{~S}_{\mathrm{t}} * \mathrm{D}_{\mathrm{c}} * \mathrm{M}_{\mathrm{t}}$ & 2 & 0.00029963 & 0.00014981 & 2.31 & 0.117 & NS \\
\hline
\end{tabular}

Note: ++ - Significant @1\%; + - Significant @ 5\%; NS - Not significant.

\subsubsection{Optimum Steaming Time for Date Juice Extraction}

Studies showed that optimum steaming time for extraction of juice from date palm fruit was 90 minutes (5,400 seconds). Figure 4 shows the increase in steaming time with the corresponding increase in moisture absorption. Moisture absorbed by date palm fruit increased gradually to a maximum point of $0.74 \mathrm{~kg}$ which corresponded to 5400 seconds (90 minutes) steaming time and fell to $0.71 \mathrm{~kg}$ at 7,200 seconds (120 minutes) steaming time after the maximum point of $0.74 \mathrm{~kg}$ and remained fairly constant with further increased in steaming time. This implies that at 90 minutes of date palm fruit steaming, the equilibrium moisture content was achieved. At this point any moisture available for absorption would not be absorbed since the intercellular voids of the fruit became saturated with moisture that any excess moisture would be rejected due to lack of accommodation. It could therefore, be said that from the data here obtained, that the optimum steaming time for extraction 
of juice from date palm fruit was 90 minutes. This is an improvement over 180 minutes steaming time [27]. In a research conducted by Owolarafe, O. K [28] on microstructural characterization of oil palm fruit, a steaming/sterilization time of 60 minutes was recommended for oil palm fruit. The disparity in steaming time of date palm fruit and oil palm fruit was in line since they are different crops. Prolong steaming time was required for date palm fruit in order to break up cell bearing nutrients of the fruit.

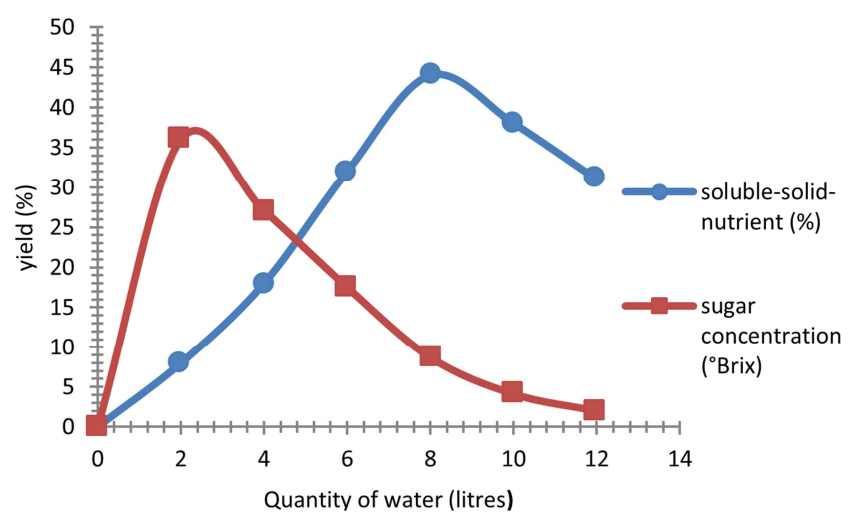

Figure 3. Optimum quantity of water for juice yield.

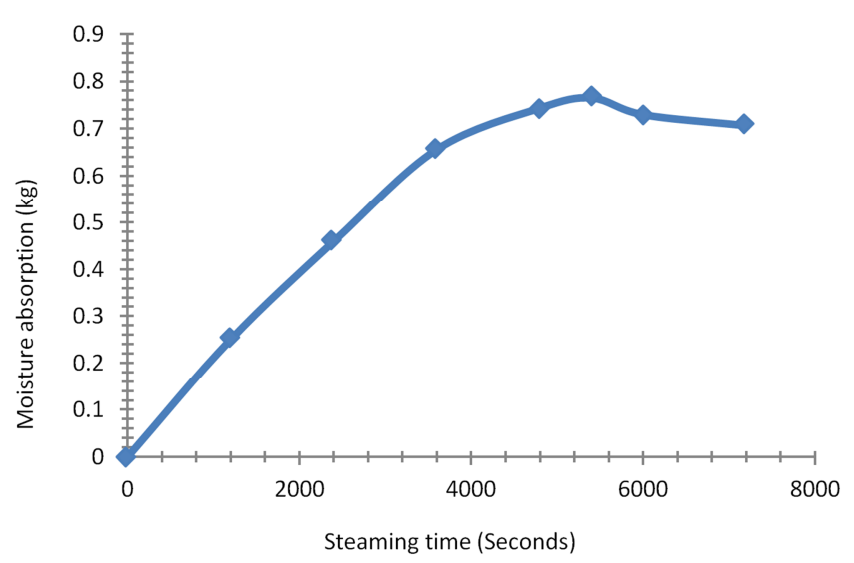

Figure 4. Optimum steaming time.

\subsubsection{Optimum Diffusion Coefficient for Date Juice Extraction}

Optimum diffusion coefficient was the diffusion coefficient that corresponded to 90 minutes (5,400 seconds) of date palm fruit steaming. The diffusion coefficient at 90 minutes fruit steaming obtained by interpolation was $4.38 \mathrm{x}$ $10^{-9} \mathrm{~m}^{2} / \mathrm{s}$ (Table 5). Diffusion coefficient was the driving force responsible for the movement of air and water molecules through the intracellular and intercellular voids of fruit mesocarp during fruit processing. Figure 5 shows increase in yield with the corresponding increase in diffusion coefficient. Maximum yield was achieved at optimum diffusion coefficient of $4.38 \times 10^{-9} \mathrm{~m}^{2} / \mathrm{s}$. The yield then remains fairly constant beyond the optimum diffusion coefficient since the intra-and-intercellular voids of the fruit mass became saturated with moisture that molecular transfer became stagnated.

\subsubsection{Optimum Digestion Time for Date Juice Extraction}

Figure 6 shows the increase in yield with the corresponding increase in digestion time. The yield increased steadily from 3 minutes of digestion time until maximum yield was achieved at 15 minutes digestion time. The digestion time of 15 minutes was then taken as the optimum digestion time. Yield obtained from fruit digested beyond 15 minutes remained fairly constant as shown by Figure 6 . Optimum digestion time was the most appropriate and economic time taken for digestion of date mesocarp. Table 5 shows the diffusion coefficients of date palm fruit at different steaming time.

Table 5. Diffusion coefficients.

\begin{tabular}{lll}
\hline S/No. & Steaming time (minutes) & Diffusion coefficients $\left(\mathbf{C}_{\mathbf{f}}\right) \times \mathbf{x 1 0}^{-9} \mathbf{~ m}^{\mathbf{2}} \mathbf{s}$ \\
\hline 1. & 0 & 0 \\
2. & 20 & 1.83536 \\
3. & 40 & 2.99181 \\
4. & 60 & 3.36578 \\
5. & 80 & 3.59591 \\
6. & 100 & 4.86168 \\
7. & 120 & 6.88498 \\
8. & 140 & 6.89534 \\
\hline
\end{tabular}

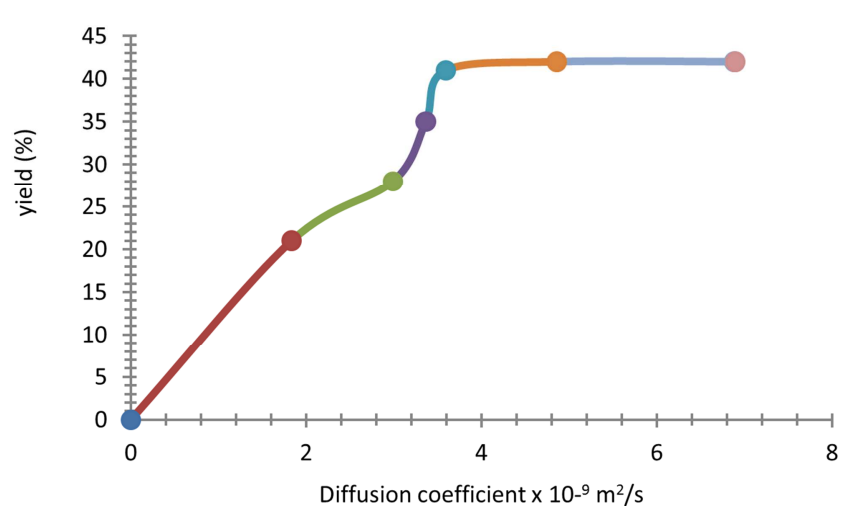

Figure 5. Optimum diffusion coefficient for juice yield.

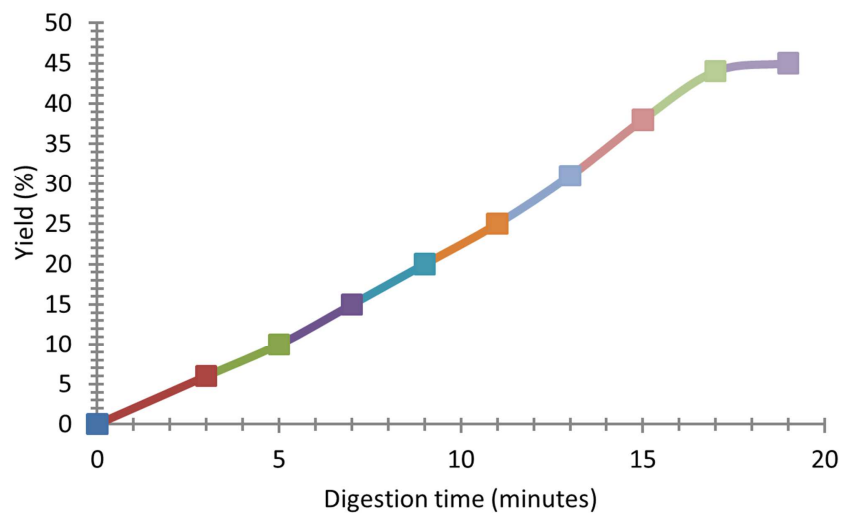

Figure 6. Optimum digestion time for juice yield.

When digestion time was less than the optimum value of 15 minutes, a small fragment of date mesocarp was mechanically digested which did not significantly affect dissolution of water-soluble-nutrients thereby retarding juice yield. In a situation where optimum digestion time was exceeded, dissolution of water-soluble-nutrients was fairly 
static and this could lead to losses in energy, time and unnecessary tear and wear of equipment. It was reported by Owolarafe, O. K [28] that appropriate digestion time stimulate cell content disintegration which will eventually results in increasing yield.

\subsection{Effect of Variables on Experimental and Predicted Yield}

The variables considered here were steaming time and diffusion coefficient. Figure 7 shows the effect of steaming time on predicted and experimental yield. Predicted yield at optimum steaming time of 90 minutes was between 56.72 and $56.82 \%$ and remained fairly constant with further increase in steaming time. Experimental yield also followed the same trend.

Figure 8 shows the effect of diffusion coefficient on predicted and experimental yield. Both predicted and experimental yield increased with corresponding increase in diffusion coefficient of $1.84 \times 10^{-9} \mathrm{~m}^{2} / \mathrm{s}$ to $4.86 \times 10^{-9} \mathrm{~m}^{2} / \mathrm{s}$ with yield remaining fairly constant after $4.86 \times 10^{-9} \mathrm{~m}^{2} / \mathrm{s}$. This was because every agricultural produce has critical values of diffusion coefficients at which diffusion of materials remain fairly constant [29-30].

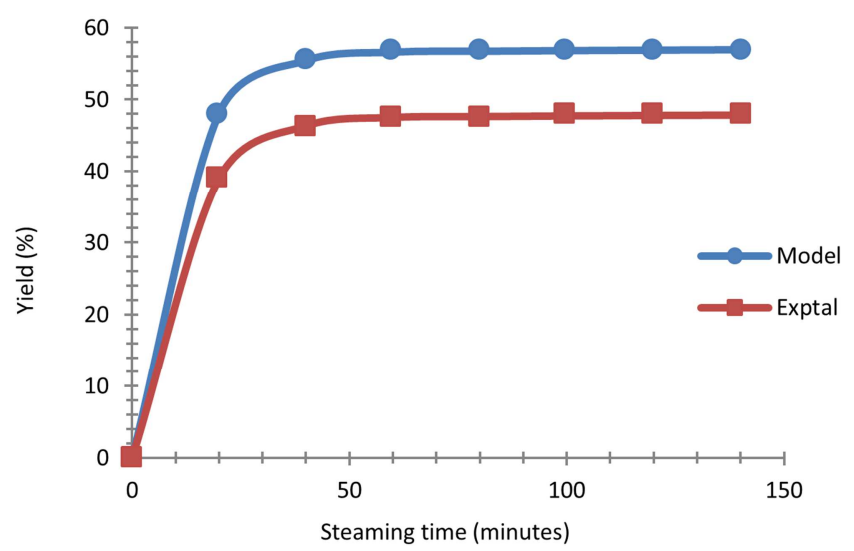

Figure 7. Effect of steaming time on yield.

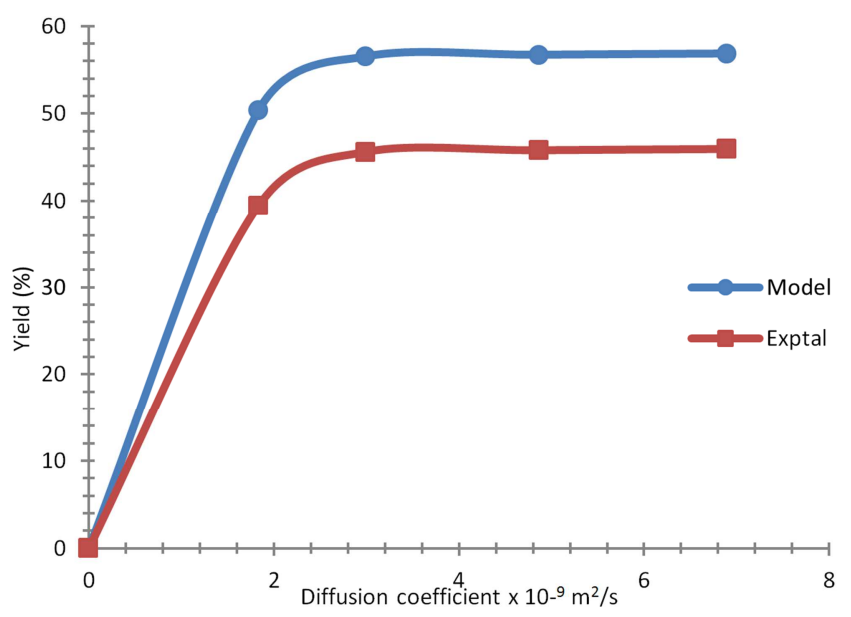

Figure 8. Effect of diffusion coefficient on yield.

\subsection{Effect of Pressure on Predicted and Experimental Yield}

Figure 9 shows the effect of pressure on predicted and experimental yield obtained at optimum values of extraction factors (steaming time, diffusion coefficient and digestion time). The Figure shows that predicted and experimental yield increased with respect to increase in pressure. This observation was also reported by [21] in the extraction of $\beta$ carotene from apricot bagasse. Figure 9 also shows that predicted and experimental yield at a pressure of 16.8 $\mathrm{MPa}$ were $53.7 \%$ and $44.8 \%$, respectively. It was further observed that a pressure of $32.8 \mathrm{MPa}$ gave $55.6 \%$ and $46.7 \%$ for predicted and experimental yield, respectively. It was observed from the results obtained in the study that there was no significant difference in yield after $16.8 \mathrm{MPa}$. Yield increased gradually with increased in pressure until $16.8 \mathrm{MPa}$ and remained fairly constant with further increased in pressure. It could therefore, be inferred from the empirical information got that extraction pressure from 14.8 to 16.8 $\mathrm{MPa}$ was sufficient for optimal extraction of juice from date palm fruit.

\subsection{Validation of Model}

Results on validation of model using error statistics showed a good correlation between predicted and experimental yield. Model predictions using optimum values of extraction factors were accurate at a percentage error of $2.56 \%$. It was reported that percentage error below $10 \%$ was assumed to be appropriate for practical purposes [1-31]. Figure 10 shows date palm fruit juice extracted under different conditions.

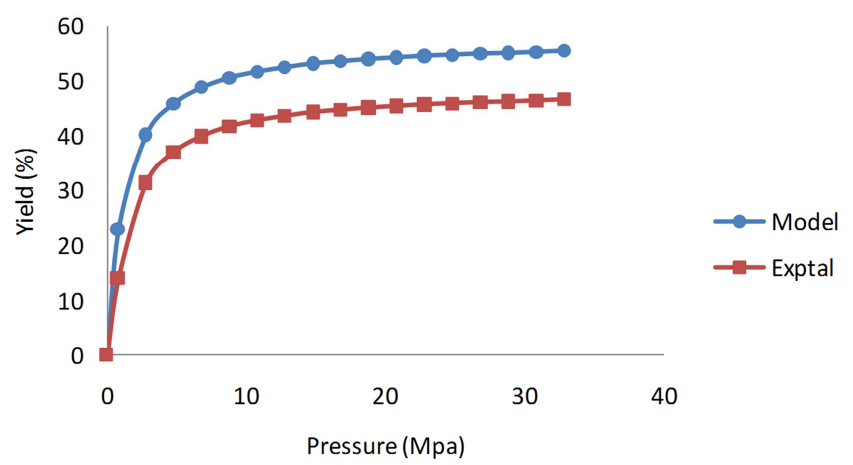

Figure 9. Effect of pressure on yield.

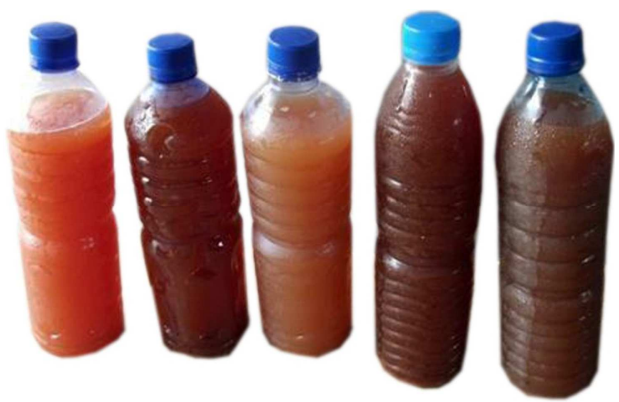

Figure 10. Date palm fruit juice. 


\section{Conclusion}

The model developed in the study accurately predicted the extraction of juice from date palm fruit. The accuracy of model prediction was shown by the results presented. The model can also be applied to predict the extraction of juice and oil from other fruits and oil bearing seeds, respectively. This is possible if the level of each factor required to facilitate extraction is known. This work has provided a road map for either the expression or extraction of juice/oil from agricultural produce. It is worthy to note that when juice was extracted from date palm fruit and subsequently dehydrated by applying heat gave rise to date syrup. Alcohol can also be obtained from date palm fruit juice depending on the handling and treatments applied to the extracted date palm fruit juice. Other part of the date palm fruit of economic importance is the seed or the stone. It was reported in literature that the seed contains oil which is of economic importance. This is an area for future research.

\section{Acknowledgements}

I wish to acknowledge NIFOR Governing Board, Executive Director/CEO and members of Internal Management Committee of Nigerian Institute for Oil Palm Research (NIFOR), Benin City, Nigeria for sponsoring the study. I also wish to express my profound gratitude to my supervisor, Prof. M. T. Ige for his mentorship and great thanks to all staff of Department of Agricultural and Environmental Engineering, Obafemi Awolowo University, Ile-Ife, Nigeria for the academic, materials and moral support given to me during the course of study.

\section{References}

[1] Omobuwajo, T. O., 1997. Modelling of screw press operation for the expression of oil from palm kernel. Unpublished Ph.D Thesis, Obafemi Awolowo University, Ile-Ife, Nigeria.

[2] Papamichail, I., Louli, V \& Magoulas, K., 2001. Supercritical fluid extraction of celery seed oil. Journal of Supercritical Fluids, 18: 213-226.

[3] Hortacsu, O., 1998. Modelling of natural materials extraction. Journal of Supercritical Fluids Fundamentals and Applications, NATO Science series, series E: Applied Sciences, 366: 499-516.

[4] Goodarznia, I \& Eikani, M. H., 1997. Supercritical carbon dioxide extraction of essential oils. Chemical Engineering Science, 53 (2): 1387-1395.

[5] Reverchon, E. \& Marrone, C., 1997. Supercritical extraction of clove bud essential oil. Chemical Engineering Science, 52: 3421-3428.

[6] Ghoreishi, S. M \& Sharifi, S., 2001. Modelling of supercritical extraction of mannitol from plane tree leaf. Journal of Pharmaceutical and Biomedical Analysis, 24: 1037-1048.

[7] Reverchon, E., 1996. Mathematical modelling of supercritical extraction of sage oil. AICHE Journal, 42: 1765-1771.
[8] Reverchon, E., Donsi, G \& Osseo, L. S., 1993. Modelling of supercritical fluid extraction from herbaceous matrices. Journal of Industrial and Engineering Chemistry Research, 32: 2721-2726.

[9] Goto, M., Roy, B. C., Kodama, A \& Hirose, T., 1998. Modelling supercritical fluid extraction process involving solute-solid interaction. Journal of Chemical Engineering, Japan, 31 (2): 171-177.

[10] Esquivel, M. M., Bernardo-Gill, G \& King, M. B., 1999. Mathematical models for supercritical Extraction of olive husk oil. Journal of Supercritical Fluids, vol. 16, pp 43-58.

[11] El Arem, A., Flamini, G., Saafi, E. B., Issaoui, M., Zayene, N., Ferchichi, A., Hammami, M., Helal, A. N. and Achour, L., 2011. Chemical and aroma volatile compositions of date palm fruit (Phoenix dactylifera 1.) fruits at three maturation stages Food Chemistry-Elsevier, 127 (4): pp 1744-1754.

[12] Emna, B. S., Mouna, L., Abdelfattah, E., Abdelfattah, Z., Mohamed, F. N., Mohamed, H. and Lotfi, A., 2011. Protective effect of date palm fruit extract (Phoenix dactylifera L.) on dimethoate induced-oxidative stress in rat liver. Experimental and Toxicologic Pathology-Elsevier, 63: 433-441

[13] Eugene, E. E., Mohammed, E. and Larisa, G., 2013. On farm diversity of date palm (Phoenix dactylifera) in Sudan: A potential Genetic Resources Conservation Strategy, www.mdpi.com/journal/sustainability, pp 339-340.

[14] Ogblechi, S. R. \& Ige, M. T., 2014. Development and evaluation of a mechanical extractor for date palm fruit juice. International Conference on Applied Social Science Research (ICASSR), Shanghai, China, pp 85-88.

[15] SAS Institute, 2002, "SAS/STAT Users' Guide”, SAS Inst., Cary, North Carolina.

[16] Durst, F., 2008. An introduction to the theory of fluid flows: Springer, Verlag Berlin Heidelberg, pp 221-230, pp 543-544.

[17] Kambe, T., 2007. Elementary fluid mechanics, Institute of Dynamical Systems, World scientific, Tokyo, pp 32-44.

[18] Geankoplis, C. J., 2003. Transport processes and separation process principles (includes unit operations), $4^{\text {th }}$ Edition, Prentice Hall, New Jersey. pp 43-48, pp 56-76.

[19] Araya, A., Thippawan, K., Suwassa, P., Supaporn, D., Peter, L. D. \& Wittaya, T., 2009. Predicting the extraction yield of nimbin from neem seeds in supercritical carbon dioxide using group contribution methods, equation of state and a shrinking core extraction model. Journal of Supercritical Fluids, 51: 3642.

[20] Amami, E., Vorobiev, E. \& Kechaou, N., 2006. Modelling of mass transfer during osmotic dehydration of apple tissue pretreated by pulsed electric field. LWT, published by Elsevier, 39: 1014-1021.

[21] Doker, O., Salgin, U., Sanal, 1., Mehmetoglu, U \& Calimi, A., 2004. Modelling of extraction of $\beta$-carotene from apricot bagasse using supercritical carbon dioxide in packed bed extractor. Journal of Supercritical Fluids, 28: 11-19.

[22] Reverchon, E., Kaziunas, A. \& Marrone, C., 2000. Supercritical carbon dioxide extraction of hiprose seed oil: experiments and mathematical modelling. Chemical Engineering Science, 55: 2195-2201. 
[23] Stroud, K. A. \& Dexter, J. B., 2003. Advanced Engineering Mathematics, $4^{\text {th }}$ Edition, Palgrave Macmillan, pp 414-419.

[24] Chan Man Fong, C. F., De Kee, D. \& Kaloni, P. N., 2003. Advanced Mathematics for Engineers and Science, World Scientific publishing Company, pp 402-420.

[25] Bird, J., 2006. Higher Engineering Mathematics, $5^{\text {th }}$ Edition, pp 515-658.

[26] Adekalu, K. O. \& Fapohunda, H. O., 2006. A numerical model to predict crop yield from soil water deficit. Biosystems Engineering, 94 (3): 359-372.

[27] S. R. Ogblechi, M. T. Ige, C. O. Ilechie, D. O. M. Enonuya and I. L. Gold, 2018. Development of a mechanical extractor for date palm fruit juice processing. Journal of Research in Engineering, 5 (1): pp 40-47.
[28] Owolarafe, O. K. \& Faborode, M. O., 2008. Micro-structural characterization of palm fruit at sterilization and digestion stages in relation to oil expression, Journal of Food Engineering, 85 (4): 598-605.

[29] Mohsenin, N. N., 1980. Thermal properties of plant and agricultural materials. Gordon and Beach science publishers, New York. pp 21-48.

[30] Serpil, S. \& Servet, G. S., 2006. Physical properties of foods. Springer, pp 193-218.

[31] Omobuwajo, T. O., Ige, M. T. \& Ajayi, O. A., 1999. Theoretical prediction of extrusion pressure and oil flow rate during screw press expeller processing of palm kernel seeds. Journal of Food Engineering, U. K. 38: 469-485. 